\title{
Steroidal control of gonadotrophin secretion in the orchidectomized dog*
}

\author{
M. Winter, J. Pirmann, R. E. Falvo, B. D. Schanbacher $†$ and
}

J. Miller $\ddagger$

\begin{abstract}
Department of Medical Physiology/Pharmacology, Southern Illinois University School of Medicine, Carbondale, Illinois 62901, $\uparrow$ Roman L. Hruska, U.S. Meat Animal

Research Center, SEA-AR, U.S. Department of Agriculture, Clay Center, Nebraska 68933, and $\ddagger$ Division of Statistics and Measurement, Southern Illinois University

School of Medicine, Springfield, Illinois 62708, U.S.A.
\end{abstract}

\begin{abstract}
Summary. The effects of s.c. administration of oil, testosterone, $5 \alpha$-dihydrotestosterone, $5 \alpha$-androstane-3 $\alpha, 17 \beta$-diol and oestradiol-17 $\beta$ on plasma concentrations of LH and FSH were determined in 5 orchidectomized dogs. The dosages for the androgens and oestradiol- $17 \beta$ were 500 and $50 \mu \mathrm{g} / \mathrm{kg}$ body weight, respectively. Testosterone and oestradiol- $17 \beta$ significantly reduced plasma gonadotrophin concentrations, although the onset and duration of their suppressive effects differed. Dihydrotestosterone and oil had no effect on either gonadotrophin. Administration of androstanediol had no effect on plasma concentrations of LH but did cause a temporary and significant reduction in FSH. It is concluded that testosterone and oestradiol-17 $\beta$ are major regulators of gonadotrophin secretion in the male dog, but the $5 \alpha$-reduction of testosterone seems to play only a minor role in this control.
\end{abstract}

\section{Introduction}

In the male mammal in general, and in the male dog in particular, the fine details of the endocrine control of luteinizing hormone ( $\mathrm{LH}$ ) and follicle-stimulating hormone (FSH) secretion are poorly understood. Since the neuroendocrine axis of the male dog has been the subject of very little research, we have been investigating the hypothalamic-pituitary-testicular axis of this species. Over a 24-h period, peaks of $\mathrm{LH}$ are followed approximately $50 \mathrm{~min}$ later by increases in the plasma concentrations of testosterone (DePalatis, Moore \& Falvo, 1978). This relationship between LH and testosterone, however, was not observed when dogs were examined twice monthly over a 12-month period and indicated that some other hormone may be involved in gonadotrophin regulation in this species (Falvo, DePalatis, Moore, Kepic \& Miller, 1980). Other data have indicated that, in orchidectomized dogs, testosterone replacement within physiological limits could maintain plasma concentrations of both LH (Vincent, Kepic, Lathrop \& Falvo, 1979) and FSH (Falvo \& Vincent, 1980) at concentrations similar to those observed in the entire untreated animal. Likewise, we (R. E. Falvo, M. Gerrity, J. Pirmann, M. Winter, D. L. Vincent \& J. Miller, unpublished) and others (Jones \& Boyns, 1974) have found that, in the dog, testosterone pretreatment does not affect the response of pituitary LH to luteinizing hormone-releasing hormone stimulation. Since the negative feedback effects of the testis on

* Reprint requests to Dr R. E. Falvo, School of Medicine, Lindegren Hall, Southern Illinois University, Carbondale, Illinois 62901, U.S.A. 
gonadotrophin secretion may be mediated centrally by testosterone itself or by one of its androgenic or oestrogenic metabolites, it seemed appropriate to compare the effects of the aromatizable (testosterone) and non-aromatizable (5a-dihydrotestosterone and $5 \alpha$-androstan$3 \alpha, 17 \beta$-diol) androgens as well as oestradiol-17 $\beta$ on the release of pituitary LH and FSH in recently orchidectomized dogs. We have previously reported the effects of testosterone and testosterone propionate on LH release in entire and orchidectomized dogs (Falvo, Vincent, Lathrop \& Toenjes, 1979), but no data exist which show the relative effects of androgenic and oestrogenic steroids in affecting LH and FSH secretion after orchidectomy in the dog. We also report on the validation and utilization of a heterologous radioimmunoassay for plasma concentrations of canine FSH.

\section{Materials and Methods}

\section{Animals}

Five adult male mongrel dogs $(12 \cdot 3-22.7 \mathrm{~kg}$ body weight) were housed individually in the SIU-C Vivarium under controlled lighting conditions ( $12 \mathrm{~h}$ light $(06: 00-18: 00 \mathrm{~h}) / 24 \mathrm{~h})$. Water and dog chow were available ad libitum. All dogs were orchidectomized via an inguinal approach and fitted with indwelling jugular cannulae. One week following orchidectomy all dogs were injected s.c. with sesame oil, testosterone, dihydrotestosterone, oestradiol-17 $\beta$ or $5 \alpha$-androstan-3 $3,17 \beta$-diol. The dosages for the androgens and oestradiol were 500 and 50 $\mu \mathrm{g} / \mathrm{kg}$ body weight, respectively, in a sesame oil vehicle. The 5 dogs were treated with oil and the 4 steroids in 5 different orders according to a $5 \times 5$ Latin Square design (Table 1). Such a design provides for an averaging out and controlling for dog and time of treatment effects when examining the steroid and oil effects over time of day. The complete design is one of repeated measures over time.

Table 1. Sequence of steroid administration* to orchidectomized dogs used in this study (Latin Square Design)

\begin{tabular}{cccccc}
\hline & \multicolumn{5}{c}{ Days after orchidectomy } \\
\cline { 2 - 6 } Dog No. & 7 & 11 & 15 & 19 & 23 \\
\hline 7889 & Oil & $\mathrm{T}$ & DHT & $3 \alpha$-diol & $\mathrm{E}_{2}$ \\
7723 & $\mathrm{E}_{2}$ & Oil & $\mathrm{T}$ & DHT & $3 \alpha$-diol \\
304 & $\mathrm{DHT}$ & $3 \alpha$-diol & $\mathrm{E}_{2}$ & Oil & $\mathrm{T}$ \\
301 & $3 \alpha$-diol & $\mathrm{E}_{2}$ & Oil & $\mathrm{T}$ & DHT \\
356 & $\mathrm{~T}$ & DHT & $3 \alpha$-diol & $\mathrm{E}_{2}$ & Oil \\
\hline
\end{tabular}

${ }^{*} \mathrm{~T}=$ testosterone; $\mathrm{E}_{2}=$ oestradiol-17 $\beta ; \mathrm{DHT}=5 \alpha$-dihydrotestosterone; $3 \alpha$-diol $=5 \alpha$-androstane- $3 \alpha, 17 \beta$-diol.

Blood samples were withdrawn at 08:00, 09:00, 10:00, 11:00, 12:00, 15:00, 21:00 and 09:00 h. All steroids were administered immediately after the first 09:00 blood sample. The plasma was separated and frozen at $-20^{\circ} \mathrm{C}$ until assayed for gonadotrophin concentrations.

\section{Gonadotrophin assays}

$L H$. Concentrations of plasma LH were determined in duplicate $200 \mu$ aliquots by a double-antibody radioimmunoassay (RIA) procedure previously described by DePalatis et al. (1978). This assay utilizes iodinated ovine LH (LER-1056-62), anti-ovine LH (No. 15 of G.D. Niswender) and purified canine LH (LER-1685-1) as the standard. The intra-assay coefficient of variation is $11 \%$ for this assay. Values for $\mathrm{LH}$ in the intact and orchidectomized dogs have been shown by us to be in the range of $0 \cdot 2-12 \cdot 0 \mathrm{ng} / \mathrm{ml}$ and $13 \cdot 0-50 \cdot 0 \mathrm{ng} / \mathrm{ml}$, respectively. 
FSH. Concentrations of plasma FSH were measured (B.D.S. at Clay Center) using a newly developed heterologous double-antibody RIA procedure for canine FSH. The rabbit antiserum to human FSH (M91) furnished by Dr W. R. Butt has been described and validated for use in sheep (McNeilly, McNeilly, Walton \& Cunningham, 1976). Purified ovine FSH (LER-1181-3; approximately $35 \times$ NIH-FSH-S1) was iodinated by the chloramine T method of Greenwood, Hunter \& Glover (1963) as modified by Schanbacher \& Ford (1977).

In brief, $2.5 \mu \mathrm{g}$ purified ovine FSH was reacted with $0.5 \mathrm{mCi}{ }^{125} \mathrm{I}$ (New England Nuclear) and $2 \mu \mathrm{g}$ chloramine $\mathrm{T}$ for $30 \mathrm{sec}$. Iodinated FSH was separated from free iodide on Bio-Gel P-100 columns. On the day of use, the iodinated preparation was rechromatographed on a microcolumn containing $0.5 \mathrm{~g}$ Bio-Rad AG 1-X10 anion exchange resin and equilibrated with assay buffer. Binding curves were generated with the canine reference standard (LER-1685-3A). Diluted FSH antiserum $(400 \mu \mathrm{l}, 1: 10000)$ containing $0.75 \%$ normal rabbit serum and $100 \mu \mathrm{l}$ ${ }^{125}$ I-labelled FSH tracer (10000 c.p.m.) was added to each assay tube containing sample or reference standard. Bound and free hormone was separated by centrifugation following the addition of sheep anti-rabbit gamma globulin. Bound radioactivity was counted in a Packard gamma spectrometer.

Inhibition lines for entire (120 ng FSH/ml) and castrated $(485 \mathrm{ng} \mathrm{FSH} / \mathrm{ml})$ male dog serum paralleled the binding of the reference standard (Text-fig. 1). Specificity was confirmed by testing for binding inhibition with canine LH (LER-1685-1). Binding was not affected by small $(0 \cdot 1 \mathrm{ng}$ ) or large (100 ng) dosages of canine LH. The minimal detectable amount of FSH in this assay was $12.5 \mathrm{ng}$ and the working range of the assay extended from 62.5 to $2000 \mathrm{ng} / \mathrm{ml}$. Within- and between-assay variability was determined for 4 samples within each of 4 assays; the intra-assay coefficients of variation were 5.3 and $6.6 \%$ for entire and castrated male dog serum, respectively and the interassay values were 8.7 and $4.1 \%$.

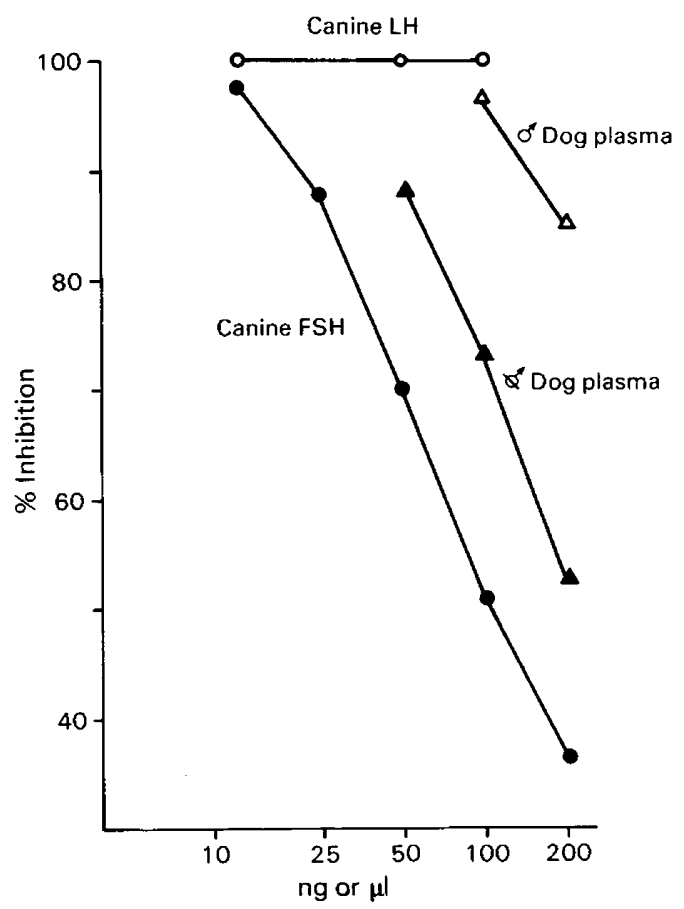

Text-6ig. 1. Inhibition lines of canine FSH standard (LER-1685-3A), canine LH standard (LER-1685-1), intact male dog plasma, and orchidectomized dog plasma when competed against ${ }^{125}$ I-labelled iodination grade ovine FSH (LER-1881-3). 


\section{Analyses}

Statistical analysis included an analysis of variance (ANOVA) (Dixon \& Massey, 1969) appropriate to the design followed by post-hoc comparisons of means using Tukey's range test (Kirk, 1968) at the 5\% significance level. Since observations were made at baseline (08:00-09:00 h) as well as during the peak periods of steroid treatment, the ANOVA indicated steroid effects with a significant time-by-treatment interaction. That is, a change in hormone levels induced by treatment and observed over part of the $24 \mathrm{~h}$ period of observation resulted in a large mean square for the time-by-treatment interaction.

\section{Results}

The results of the ANOVA for the response of plasma LH to the various steroid treatments are shown in Table 2. Averaging over the time of day factor, there were significant dog and order effects but no significant treatment effect. Considering the time of day factor, there was a significant time-by-treatment interaction indicating a changing $\mathrm{LH}$ level over time for some treatment groups; there were no other interactions with time.
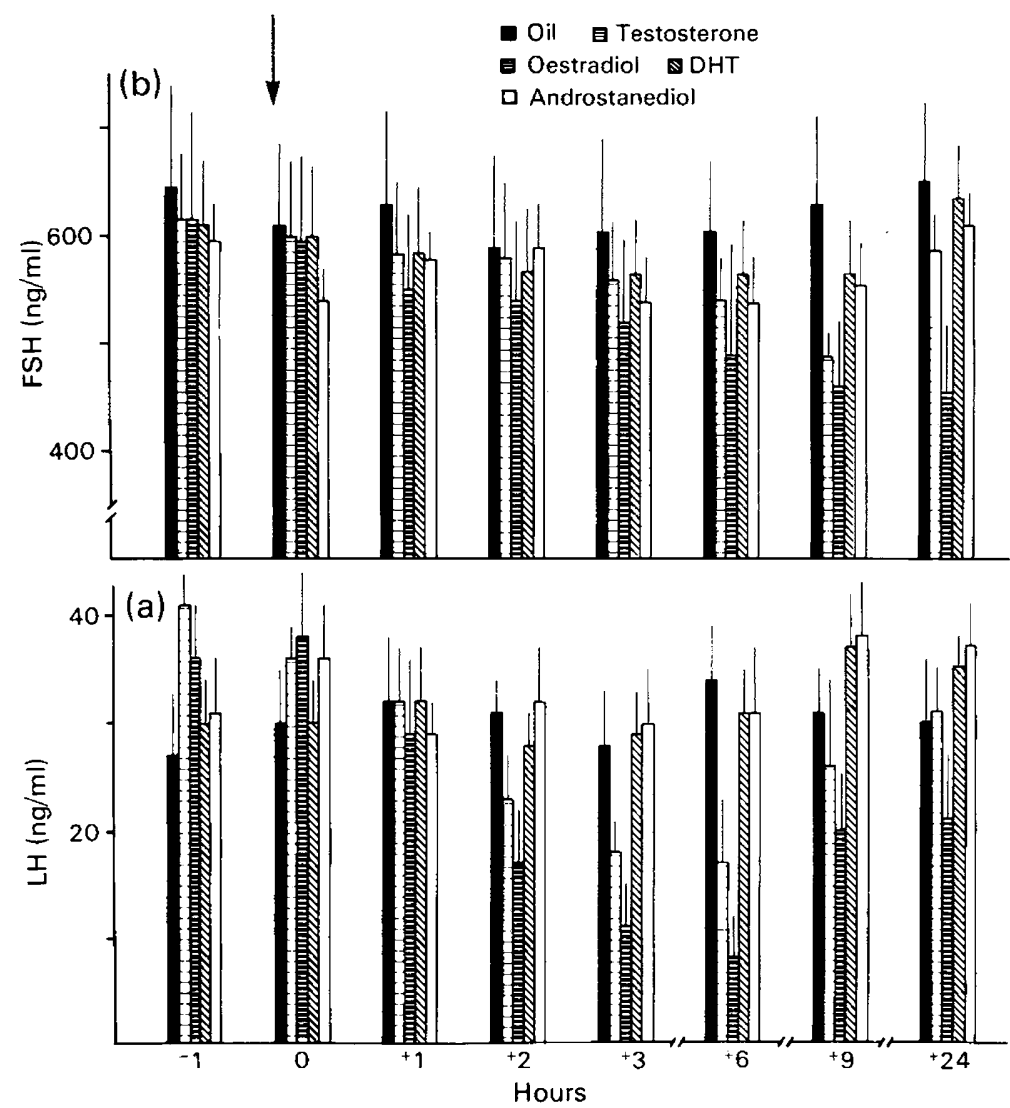

Text-fig. 2. Mean \pm s.e.m. plasma concentrations of (a) LH and (b) FSH throughout the study period in orchidectomized dogs injected (arrow) s.c. with oil or steroids. LH values are expressed in terms of ng LER-1685-1/ml; LER-1685-1 has an LH activity of 0.025 units NIH-LH-S1/mg. FSH values are expressed in terms of ng LER-1685-3A/ml; LER-1685-3A has an FSH activity of 0.50 units NIH-FSH-S1/mg. 
Table 2. Results of the analysis of variance for serum concentrations of LH and FSH after treatment with oil and various steroids

\begin{tabular}{|c|c|c|c|c|c|c|c|c|}
\hline \multirow[b]{2}{*}{ Source } & \multicolumn{4}{|c|}{ LH } & \multicolumn{4}{|c|}{ FSH } \\
\hline & d.f. & Mean Square & $\mathrm{F}$ & $P$ & d.f. & Mean Square & $\mathrm{F}$ & $P$ \\
\hline Dog & 4 & 2117.8 & 9.31 & 0.005 & 4 & 268005 & $13 \cdot 76$ & 0.0002 \\
\hline Day & 4 & 1243.2 & 5.46 & 0.01 & 4 & 412287 & $21 \cdot 16$ & 0.0001 \\
\hline Treatment & 4 & $670 \cdot 8$ & 2.95 & NS & 4 & 40594 & 2.08 & NS \\
\hline Error & 12 & 227.5 & & & 12 & 19482 & & \\
\hline Time of day & 7 & $411 \cdot 2$ & 6.49 & 0.0001 & 7 & 14765 & $13 \cdot 18$ & 0.0001 \\
\hline Time $\times$ dog & 28 & 69.7 & $1 \cdot 10$ & NS & 28 & 1657 & 1.48 & NS \\
\hline Time $x$ day & 28 & $95 \cdot 1$ & $1 \cdot 50$ & NS & 28 & 2900 & 2.59 & 0.0005 \\
\hline Time $\times$ treatment & 28 & 178.4 & $2 \cdot 82$ & 0.0001 & 28 & 4900 & $4 \cdot 30$ & 0.0001 \\
\hline Error & 84 & 63.3 & & & 84 & 1120 & & \\
\hline
\end{tabular}

NS $=$ not significant

The plasma concentrations of $\mathrm{LH}$ throughout the study period are shown in Text-fig. 2 . Using Tukey's range test in comparing response over time for each treatment, the following effects were noted. Administration of oil, dihydrotestosterone and androstanediol had no effect on plasma LH. Testosterone caused a significant reduction in plasma LH from 3 to $6 \mathrm{~h}$ after injection when compared to baseline levels. Oestradiol showed a similar reduction in plasma LH from $2 \mathrm{~h}$ and throughout the $24 \mathrm{~h}$ period. Testosterone and oestradiol both caused maximal suppression of plasma LH at $6 \mathrm{~h}$, but oestradiol suppression of plasma LH lasted longer.

The results of the ANOVA for plasma concentration of FSH are shown in Table 2. Averaging over the time of day factor, there were significant dog and order effects but no treatment effect. Including the time of day factor showed significant order-by-time and treatment-by-time interaction effects. Not only did order of steroid administration (or total time in the study) affect FSH level, it affected it differently at different periods of observation. As before, the time by treatment interaction indicated a changing FSH level over time for some treatment groups.

The plasma concentrations of FSH throughout the study period are shown in Text-fig. 2 . Using Tukey's range test in comparing responses over time for each treatment, the following effects were noted. Administration of oil and dihydrotestosterone had no effect on plasma FSH. Administration of androstanediol caused a significant reduction in plasma FSH at $3 \mathrm{~h}$ after injection when compared to baseline levels. Both testosterone and oestradiol in the post-injection period caused significant reductions in plasma FSH when compared to baseline. Oestradiol administration caused suppression of plasma FSH from $3 \mathrm{~h}$ after injection throughout the $24 \mathrm{~h}$ period, whereas testosterone suppression was only apparent at 6 and $9 \mathrm{~h}$ after injection.

\section{Discussion}

The results of this study indicate that, in the orchidectomized dog, testosterone and oestradiol caused significant reductions in plasma concentrations of both $\mathrm{LH}$ and FSH. Both steroids caused maximal reduction of $\mathrm{LH}$ at similar time periods following administration, but the inhibitory response of oestradiol lasted longer. The suppression of FSH by oestradiol occurred more quickly and was of longer duration when compared with testosterone.

In contrast to dihydrotestosterone, which had no effect on LH or FSH, androstanediol caused a reduction in the plasma concentration of $\mathrm{FSH}$.

It is difficult to compare these results with others in the literature because of the existence of multiple variables between studies. These variables include differences in species, dosages, 
vehicles, routes of administration, interval between castration and treatment and the use of various steroid preparations (e.g. free or esterified). Taking all of these variables into consideration, there are still general patterns which emerge regarding the steroidal control of gonadotrophin secretion in the male. Results of the present study of the orchidectomized dog are in agreement with studies of the rat (Gay \& Dever, 1971; Eldridge \& Mahesh, 1974; Verjans, Eik-Nes, Aafles, Vels \& van der Molen, 1974), the sheep (Schanbacher \& Ford, 1977; Schanbacher, 1980), the guinea-pig (Buhl \& Cornette, 1980) and the monkey (Plant, Hess, Hotchkiss \& Knobil, 1978) which have shown that treatment of orchidectomized animals with testosterone and oestradiol reduces plasma concentrations of both LH and FSH.

In the orchidectomized rat (Eldridge \& Mahesh, 1974; Verjans et al., 1974) and guinea-pig (Buhl \& Cornette, 1980), dihydrotestosterone reduces the plasma concentrations of both LH and FSH. In the orchidectomized pig low doses of this androgen increase whereas high doses decrease LH concentrations (Parvizi, Elsaesser, Smidt \& Ellendorff, 1977). In contrast, dihydrotestosterone has no effect on FSH or LH in the orchidectomized sheep (Schanbacher \& Ford, 1977) or dog (present study).

The effects of $5 \alpha$-androstan-3a,17 $\beta$-diol on LH and FSH secretion have not been extensively studied. There are reports indicating suppression of LH (Martini, Celloti, Massa \& Motta, 1978) and FSH (Robaire, 1980) by this androgen in the orchidectomized rat. The results of the present study indicated no effect on $\mathrm{LH}$, but there was a short-lasting suppression of FSH. The data regarding FSH in the present study must be interpreted with caution because the response was small and the sequence of steroid administration may have affected the results.

The present data indicate that testosterone and oestradiol are involved in the control of $\mathrm{LH}$ and FSH secretion. Although the $5 \alpha$-reduction of testosterone to dihydrotestosterone is not involved in this regulatory process, the importance of central versus peripheral aromatization of testosterone to oestradiol in the regulation of gonadotrophin secretion needs to be clarified. Whether testosterone is directly involved in negative feedback or whether its conversion to oestrogens is required for activity remains to be determined. It will be necessary to inhibit selectively both the aromatase and $5 \alpha$-reductase enzymes to resolve this issue.

We thank Ms Theresa Brandon for technical help; Dr G. D. Niswender, Colorado State University, Fort Collins, for the LH antisera; and Dr L. E. Reichert, Jr, Albany Medical Center, Albany, New York, for the canine standards and ovine LH and FSH.

\section{References}

Buhl, A.E. \& Cornette, J.C. (1980) The influences of testosterone $(\mathrm{T})$ estradiol-17 $\beta$ (E) and dihydrotestosterone (DHT) on circulating $\mathrm{LH}$ and FSH in castrate male guinea pigs. Biol. Reprod. Suppl. 1, Abstr. 144.

DePalatis, L., Moore, J. \& Falvo, R.E. (1978) Plasma concentrations of testosterone and $\mathrm{LH}$ in the male dog. J. Reprod. Fert. 52, 201-207.

Dixon, W.J. \& Massey, F.J. (1969) Introduction to Statistical A nalysis. McGraw-Hill, Inc., New York.

Eldridge, J.C. \& Mahesh, V.B. (1974) Pituitary gonadal axis before puberty: evaluation of testicular steroids in the male rat. Biol. Reprod. 11, 385-395.

Falvo, R.E. \& Vincent, D.L. (1980) Testosterone regulation of follicle-stimulating hormone in the male dog. J. Androl. 1, 197-201.

Falvo, R.E., Vincent, D.L., Lathrop, J.C. \& Toenjes, A. (1979) Effects of testosterone and testosterone propionate administration on luteinizing hormone secretion in the male mongrel dog. Biol. Reprod. 21, $807-812$.

Falvo, R.E., DePalatis, L.R., Moore, J., Kepic, T.A. \& Miller, J. (1980) Annual variations in plasma levels of testosterone and luteinizing hormone in the laboratory male mongrel dog. $J$. Endocr. 86, 425430.

Gay, V.L. \& Dever, N.W. (1971) Effects of testosterone propionate and estradiol benzoate alone or in combination on serum LH and FSH in orchidectomized rats. Endocrinology 89, 161-168.

Greenwood, F.C., Hunter, W.M. \& Glover, J.S. (1963) The preparation of I-labelled human growth hormone of high specific radioactivity. Biochem. J. 89, $114-123$.

Jones, G.E. \& Boyns, A.R. (1974) Effect of gonadal steroids on the pituitary responsiveness to synthetic luteinizing hormone releasing hormone in the male dog. J. Endocr. 61, 123-131. 
Kirk, R.E. (1968) Experimental Design; Procedures for the Behavioral Sciences. Brooks/Cole Publishing Co., Belmont, California.

Martini, L., Celotti, F., Massa, R. \& Motta, M. (1978) Studies on the mode of action of androgens in neuroendocrine tissues. J. Steroid Biochem. 9, 411-417.

McNeilly, J.R., McNeilly, A.S., Walton, J.S. \& Cunningham, F.J. (1976) Development and application of a heterologous radioimmunoassay for ovine follicle-stimulating hormone. J. Endocr. 70, 69-79.

Parvizi, N., Elsaesser, R., Smidt, D. \& Ellendorfi, F. (1977) Effects of intracerebral implantation, microinjection and peripheral application of sexual steroids on plasma luteinizing hormone levels in the male miniature pig. Endocrinology 101, 1078-1087.

Plant, T.M., Hess, D.L., Hotchkiss, J. \& Knobil, E. (1978) Testosterone and the control of gonadotropin secretion in the male rhesus monkey. Endocrinology 103, 535-541.

Robaire, B. (1980) Effects of testosterone and of its
$5 \alpha$-reduced metabolites on the post-orchidectomy rise of serum gonadotropins in male rats. Biol. Reprod., Suppl. 3, Abstr. 145.

Schanbacher, B.D. (1980) Testosterone regulation of luteinizing hormone and follicle-stimulating hormone secretion in young male lambs. J. Anim. Sci. 51, 679-684.

Schanbacher, B.D. \& Ford, J.J. (1977) Gonadotropin secretion in cryptorchid and castrate rams and the acute effects of exogenous steroid treatment. Endocrinology 100, 387-393.

Verjans, H.L., Eik-Nes, K.B., Aafles, J.H., Vels, FJ.M. \& van der Molen, H.J. (1974) Effects of testosterone propionate, $5 \alpha$-dihydrotestosterone propionate and oestradiol benzoate on serum levels of LH and FSH in the castrated adult male rat. Acta endocr., Copenh. 77, 643-654.

Vincent, D.L., Kepic, T.A., Lathrop, J.C. \& Falvo, R.E. (1979) Testosterone regulation of luteinizing hormone secretion in the male dog. Int. J. Androl. 2, 241-249.

Received 27 May 1981 